\title{
Profile of users intoxicated by drugs of abuse and association with death
}

\author{
Perfil de usuários intoxicados por drogas de abuso e associação com o óbito
}

Lúcia Margarete dos Reis ${ }^{1}$, Aroldo Gavioli ${ }^{2}$, Flavia Antunes ${ }^{2}$, Michele Cristina Santos Silvino ${ }^{1}$, Natalina Maria da Rosa $^{2}$, Magda Lúcia Félix de Oliveira ${ }^{1}$

Objective: to characterize the profile of users intoxicated by drugs of abuse reported to a center of information and toxicological assistance and related this to the occurrence of deaths. Methods: study of case series reported in the 2010-2011 biennium after active case finding. Data were obtained from epidemiological records filed in the center and submitted to univariate analysis, with chi-squared test and Fischer test. Results: three hundred and thirty nine cases were found, most were men (87.3\%), with basic education (61.0\%) and elderly (37.2\%). Alcohol use (83.8\%) and chronic intoxications (89.9\%) were predominant. Clinical complications were present in most medical diagnoses (63.4\%). However, mortality was higher in the event deferral by cold and fire weapons. Conclusion: the consumption of drugs of abuse influences morbidity and mortality, particularly in men aged at 60 years or above and with low level of education.

Descriptors: Disease Notification; Epidemiological Surveillance; Street Drugs; Alcoholic Intoxication.

Objetivo: caracterizar o perfil de usuários intoxicados por drogas de abuso notificados em um centro de informação e assistência toxicológica relacionando com a ocorrência de óbitos. Métodos: estudo de série de casos notificados no biênio 2010-2011, após busca ativa de casos. Os dados foram obtidos das fichas epidemiológicas arquivadas no centro, e submetidos à análise estatística univariada, com teste qui quadrado e de Fischer. Resultados: encontrou-se 339 casos, a maioria homens (87,3\%), escolaridade fundamental (61,0\%), e idosos $(37,2 \%)$. Uso de álcool $(83,8 \%)$ e intoxicações crônicas $(89,9 \%)$ foram predominantes. Intercorrências clínicas estavam presentes na maioria dos diagnósticos médicos $(63,4 \%)$, no entanto, a letalidade foi maior na ocorrência de ferimento por armas branca e de fogo. Conclusão: 0 consumo de drogas de abuso influencia a morbimortalidade, principalmente em homens, na faixa etária de 60 anos ou mais e com menor nível de escolaridade.

Descritores: Notificação de Doenças; Vigilância Epidemiológica; Drogas Ilícitas; Intoxicação Alcoólica.

\footnotetext{
${ }^{1}$ Universidade Estadual de Maringá. Maringá, PR, Brazil.

${ }^{2}$ Hospital Universitário Regional de Maringá. Maringá, PR, Brazil. 


\section{Introduction}

The use of drugs of abuse is considered a serious social and public health problem worldwide and constitutes a risk factor for automobile and violence accidents that culminate in death, temporary and permanent functional losses, generating high social and economic costs ${ }^{(1-2)}$.

The general population is affected by drug use, addiction, commercialization and trafficking, and also by the violence associated with these social behaviors. In Brazil, alcohol consumption, a lawful drug and of easy access to people, is associated with most of the traffic and occupational accidents and cases of domestic violence ${ }^{(3)}$. The increase in the consumption of licit and illicit drugs and their direct and indirect impact on societies raise reflections on ways to give effective answers to problems that arise every day in this context $t^{(4-5)}$.

The drug use/abuse and its effects on society are object of research to the construction of actions and public policies in the field of health, and are usually monitored through cross-sectional surveys in samples for large regions or cities. In loco-regional level, epidemiological surveillance systems to measure the effect of drug abuse on the health of the population are still incipient, and a process of continuous and effective monitoring is lacking, contributing to the absence of data to score or redirect interventions at this level ${ }^{(5-6)}$.

Epidemiological surveillance of poisonings, called toxicovigilance, is understood as a set of measures and actions that aims to understand the occurrence of intoxication and related factors and to promote its prevention or control ${ }^{(7: 79)}$. However, the underreporting of cases is something that undermines the representativeness of the data, given the high cost of systems such as active case finding, with application in sentinel services such as Information Centers and Toxicological Assistance ${ }^{(8)}$.

The hospital environment is an important source for the detection of notifiable diseases and other emerging diseases, and it is a priority site for development of epidemiological surveillance. In Brazilian hospitals, centers of information and toxicological assistance are specialized units for the provision of information about the diagnosis and treatment of poisoning, toxicity and the risks that chemicals cause to health ${ }^{(9)}$.

Although the use of drugs of abuse has called the attention of public policies and health professionals, these events are still neglected from the epidemiological point of view. This can hinder the provision of a foundation for care planning and addressing these grievances ${ }^{(6)}$.

In this context, the present study aimed to characterize the profile of users intoxicated by drugs of abuse reported to an information center and toxicological assistance and related it to the occurrence of deaths.

\section{Methods}

This was a study of series of cases of poisoning by drugs of abuse reported after active search for cases in the 2010-2011 biennium.

The study was conducted from a retrospective analysis of records of Epidemiologic Sheets of Toxicological Occurrence of Alcohol Intoxication and/ or Other Drugs of Abuse, filed in a Center of Information and Toxicological Care, linked to a university hospital of the Northwest of Paraná state. This service offers qualified assistance in cases of intoxication, in addition to promoting the systematization, expansion and transmission of technical and scientific knowledge concerning the prevention, control and treatment of toxicological accidents.

Reported cases notified by the method of active search were analyzed. The active search refers to intentional search, in order to identify situations of specific diseases, vulnerability and social risk, and allows to know the characteristics and specificities of the assisted population and its social reality ${ }^{(8)}$. In the Center of Information and Toxicological Assistance 
under study, the active search for cases is held in periodic visits to hospital care sectors.

The sampling process of the development of this study happened by convenience, allowing the selection of individuals based on criteria and not on statistically representativeness.

Data was obtained from the reporting forms of individuals over the age of 12, regardless of sex, with clinical symptoms of intoxication by drugs of abuse, hospitalized and notified through the system of active search. Clinical and epidemiological criteria were accepted for confirmation of the case - existence of signs and/or symptoms and compatible history of intoxication; or clinical laboratory - the existence of signs and/or symptoms and results of compatible tests. According to the criteria, 339 cases were studied.

Variables were compiled from records in the forms and categorized as follows: sex, age (12 to 19 years, 20 to 29,30 to 39 years, 40 to 49 years, 50-59 years and 60 years or more), and educational level (none, primary school, highschool, superior education or ignored); variables related to intoxication: toxic agent (alcohol, cocaine/crack, marijuana, multiple drugs), type of intoxication related to the time of use (chronic and acute); medical diagnosis associated with intoxication according to the International Classification of Diseases (ICD-10) with or without association to external causes; and admission: length of stay (less than 10 days, 11 to 20 days, 21 to 30 days, more than 31 days), hospital care (emergency room, ward, intensive care unit and others). Death was considered as the outcome variable (death or no death). The option ignored was included for all variables.

Data were entered into a spreadsheet in Microsoft Excel software 10.0 and processed by the IBM Statistical Package for the Social Sciences version 20.0. Statistical analysis consisted of describing the surveyed data through absolute and relative frequency, averages, which were subsequently submitted to univariate analysis using chi-squared test with Yates correction. When there was low numerosity $(<5)$, the
Fisher's exact test was applied to check for statistically significant relationship between the variables and the occurrence of deaths in the sample. Categories were grouped to form the contingency table, and values of $p$ $<0.05$ were considered significant.

The study complied with the formal requirements contained in the national and international regulatory standards for research involving human beings.

\section{Results}

Among the 339 cases of intoxication by drugs of abuse, most were male (87.3\%) with a sex ratio of 6.9 men for every woman. The most frequent age was 60 years or older (37.2\%) and most had only primary education (61.0\%). Twenty-eight cases of death (8.2\%) were found, occurring mainly in men (92.9\%), aged at $\geq 60$ years $(46.4 \%)$ and with basic education level (53.6\%) (Table 1).

Table 1 - Distribution of reported cases and the cases of death, according to demographic data

\begin{tabular}{|c|c|c|}
\hline \multirow{2}{*}{ Variable } & Cases & Deaths \\
\hline & $n(\%)$ & $n(\%)$ \\
\hline \multicolumn{3}{|l|}{ Gender } \\
\hline Male & $296(87.3)$ & $26(92.9)$ \\
\hline Female & $43(12.7)$ & $2(7.1)$ \\
\hline \multicolumn{3}{|l|}{ Age (years) } \\
\hline $14-19$ & $16(4.7)$ & - \\
\hline 20 to 29 & $16(4.7)$ & - \\
\hline 30 to 39 & $52(15.3)$ & $5(17.9)$ \\
\hline 40 to 49 & $62(18.3)$ & $6(21.4)$ \\
\hline 50 to 59 & $67(19.8)$ & $4(14.3)$ \\
\hline $60>$ & $126(37.2)$ & $13(46.4)$ \\
\hline \multicolumn{3}{|l|}{ Level of education } \\
\hline None & $21(6.2)$ & $6(21.4)$ \\
\hline Primary school & $207(61.1)$ & $15(53.6)$ \\
\hline High school & $57(16.8)$ & $3(10.7)$ \\
\hline Superior education & $22(6.5)$ & - \\
\hline Ignored & $32(9.4)$ & $4(14.3)$ \\
\hline Total & $339(100.0)$ & $28(8.2)$ \\
\hline
\end{tabular}


Table 2 - Distribution of reported cases and the cases of death, according to data of intoxication

\begin{tabular}{lccc}
\hline \multirow{2}{*}{ Variable } & Cases & Deaths & \multirow{2}{*}{ p-value } \\
\cline { 2 - 3 } & $\mathbf{n}(\mathbf{\%})$ & $\mathbf{n}(\mathbf{\%})$ & \\
\hline Toxic agent & & & \\
Alcohol & $284(83.8)$ & $27(96.4)$ & $0.103^{1}(0.062)^{2}$ \\
Cocaine/crack & $21(6.2)$ & - & - \\
Marijuana & $9(2.6)$ & - & - \\
Multiple drugs* & $25(7.4)$ & $1(3.6)$ & $0.707^{2}$ \\
Type of intoxication & & & \\
Chronic & $305(89.9)$ & $25(89.3)$ & $0.751^{2}$ \\
Acute & $34(10.1)$ & $3(10.7)$ & \\
Total & $339(100.0)$ & $28(100.0)$ \\
*Association with alcohol, marijuana and crack; ${ }^{1}$ Chi-square; ${ }^{2}$ Fisher's exact test
\end{tabular}

The most commonly used drug was alcohol (83.8\%), and characterized as chronic poisoning (89.9\%), however the statistical analysis showed that there was no statistically significant association between alcohol use and the occurrence of deaths (Table 2).

Regarding diagnostic consequential factors beyond the intoxication, there was a predominance of falls (12.4\%) and physical abuse (12.4\%), but the highest mortality was related to cases of injury by weapon and firearm, with an approximate ratio of one death for every three hospitalizations. In intoxication not associated with external causes, the clinical consequence of liver cirrhosis (33.3\%) and bleeding esophageal varices (30.1\%) accounted for more than half of the cases of death, but the statistical analysis did not result in significant associations.

Mostindividuals (63.1\%) remained hospitalized for a period of ten days, and the most frequent hospital sector was the emergency department (67.0\%), although high number of admissions to intensive care unit (15.6\%) were found, where most of deaths (53.5\%) occurred (Table 4).
Table 3 - Distribution of reported cases and the cases of death, according to medical diagnoses associated with intoxication

\begin{tabular}{lccc}
\hline Variable & Cases & Deaths & p-value \\
\cline { 2 - 4 } & $\mathbf{n ( \% )}$ & $\mathbf{n}(\%)$ & \\
\hline Associated with external causes & $124(36.6)$ & $9(32.2)$ & $0.092^{1}$ \\
Fall & $42(12.4)$ & $3(10.7)$ & $1.000^{2}$ \\
Physical aggression & $42(12.4)$ & - & - \\
Traffic accident & $23(6.8)$ & $1(3.6)$ & $1.000^{2}$ \\
Injury by cold weapon & $10(2.9)$ & $3(10.7)$ & $0.017^{2}$ \\
Injury by firearm & $6(1.8)$ & $2(7.1)$ & $0.060^{2}$ \\
Occupational accident & $1(0.3)$ & - & - \\
Not associated with external causes & $215(63.4)$ & $19(67.8)$ & $0.092^{2}$ \\
Cirrhosis & $113(33.3)$ & $14(50.0)$ & $0.060^{2}$ \\
Esophageal bleeding varices & $102(30.1)$ & $5(17.9)$ & \\
Total & $339(100.0)$ & $28(100.0)$ \\
\hline${ }^{1}$ Significance level of the univariate statistical analysis; ${ }^{2}$ Fisher exact test
\end{tabular}

Table 4 - Distribution of reported cases and the cases of death, according to data on hospitalization

\begin{tabular}{lccc}
\hline \multirow{2}{*}{ Variable } & Cases & Deaths & \multirow{2}{*}{$\mathbf{n}$-value } \\
\cline { 2 - 3 } Length of hospitalization (days) & & & \\
$\leq 10$ & $214(63.1)$ & $2(7.1)$ & $0.0001^{2}$ \\
11 to 20 & $71(20.9)$ & $5(17.9)$ & $0.8112^{2}$ \\
21 to 30 & $42(12.5)$ & $13(46.4)$ & $0.0001^{2}$ \\
$\geq 31$ & $12(3.5)$ & $8(28.6)$ & $0.0001^{2}$ \\
Hospitalization sector & & & \\
Emergency department & $227(67.0)$ & $5(17.9)$ & $0.0001^{2}$ \\
Nursing ward & $52(15.3)$ & $8(28.6)$ & $0.079^{1}$ \\
Intensive Care Unit & $53(15.6)$ & $15(53.5)$ & $0.0001^{1}$ \\
Others* & $7(2.1)$ & - & - \\
Total & $339(100.0)$ & $28(100.0)$ \\
\hline *Unit of semi-intensive care and maternity; ${ }^{1}$ Significance level of the univaria- \\
te statistical analysis; ${ }^{2}$ Fisher exact test
\end{tabular}

Statistically significant association was observed with hospitalization periods of less than ten days and those with prolonged hospitalizations and higher than 21 days, and in these last ones, statistical association was significant, with $\mathrm{p}<0.0001$. Deaths were associated with prolonged hospitalization $(\geq 21$ days) and admission to the intensive care unit, where cases of clinical diseases associated with chronic use of alcohol were more frequent. 


\section{Discussion}

The study provided important information about aspects that reflect the seriousness of the problem that would go unnoticed due to lack of an active surveillance system. However, it has limitations because it does not show the magnitude of the problem, since underreporting of these cases contributes to the ignorance of the actual number of intoxications and deaths related to the use of drugs of abuse in the investigated health service.

The increase of this knowledge can expand the understanding of health professionals and support improvements to the attention paid to this population profile. Data from centers of information and toxicological assistance are considered sentinels and sensors of social problems related to toxicology events $^{(6)}$ and they make possible the tracking of cases of poisoning by drug abuse and qualification of public policies offered to this population.

This study reinforces the need to strengthen epidemiological surveillance, since the study of the profile of users hospitalized due to drug abuse can be used in the formulation of indicators for monitoring the attention and implementation of local public policies, considering that many of these people get in contact with the health system due to complications resulting from drug use $\mathrm{e}^{(10)}$.

The consumption and the social impact of the use of drugs of abuse are issues of great social concern, and they justify the importance of public policies for prevention and education. It must be taken into account that the occurrence of hospitalizations resulting from drug abuse causes high social, family and individual economic losses ${ }^{(10)}$.

Data characterization of the study population corroborate a research, with similar percentages, that indicates a predominance of male users, especially over the age of 50 years, with low education and alcohol use ${ }^{(11)}$.
It is likely that the abuse of alcohol has become a problem for these people due to chronic use of drugs; these individuals began to show clinical health problems due to the chronic use of drugs. Chronic use of alcohol may be related to various clinical conditions as shown in this study.

Regarding the prevalence of alcohol intoxication, a research indicates that alcohol abuse causes significant morbidity and mortality and cause major economic damage worldwide and alcohol dependence assumes a high prevalence when compared to many other illnesses, representing one of the major public health problems nowadays ${ }^{(11-12)}$. Corroborating these data, a intoxication control center in Spain also found the use of alcohol in $70.4 \%$ of all intoxications. Also, in the last decade, the use of cocaine has gained importance in cases of intoxication by drug abuse, setting the most predominant illicit $\operatorname{drug}^{(11)}$, causing the study population to become also part of this statistic.

The pattern of drug consumption is a dynamic phenomenon and causes the user to try different types of drugs, who often makes combined use of licit and illicit drugs. The use of multiple drugs simultaneously or in sequence is increasing in several countries among both young people and adults. This is an indicative factor of greater severity and greater chance of development of dependency. A research showed polydrug use with combination of two or more drugs, the most common being alcohol, marijuana and cocaine ${ }^{(6,11-12)}$. The pattern of drug use of the investigated cases followed this trend.

There are several risk factors for polydrug use. The social, economic and individual aspects stand out, what makes it more difficult to control the addiction $^{(13-15)}$. Drug use often starts in adolescence, and the first drugs used are usually lawful ones, alcohol and tobacco. The progression to dependence on multiple drugs is associated with external pressures, due to peer pressure for using drugs 
especially in younger users $\left(<30\right.$ years ${ }^{(15)}$. Physical trauma comes as a result of changed behavior caused by drug use, often associated with acute intoxications. Intoxicated individuals who had injuries firearm and cold weapons were unusual. However, high mortality with statistical significance associated with deaths were observed among these, corroborating other studies related violence, trauma, mortality and use of drugs $^{(6,14)}$.

The consumption and sale of drugs are recognized as the major risk factors for violence and death by homicide, as violence is the form usually adopted to resolve conflicts and expand market share. This constitutes a problem that burdens the public financial resources, causing damage to the individual, to families and to society ${ }^{(16-17)}$.

The high percentage of chronic intoxication observed in the present study (89.9\%) follows the increase of chronic intoxications observed in the last decade $^{(11)}$. Chronic drug use causes behavioral changes, particularly aggressiveness, with consequent family and domestic conflicts and urban violence; organic impairments, such as hypertension, gastrointestinal and liver problems; and mental disorders such as depression ${ }^{(5,11)}$.

Among users with medical diagnoses unrelated to external causes, high frequency of liver cirrhosis and bleeding esophageal varices were observed, most likely due to chronic alcohol use, and with statistically significant association with occurrence of deaths. These findings are consistent with other researches that showed the chronic use of alcohol as a cause of serious health problems with high morbidity and mortality mainly related to clinical complications ${ }^{(11-12,14)}$.

Regarding hospitalization time-length, it was found that most of the drug users remained hospitalized for a period of at least ten days. However, there was a significant number of people with serious complications requiring surgery, mechanical ventilation and intensive care and deaths that occurred in $8.2 \%$.
The statistical analysis showed an association of prolonged hospitalization and admission in intensive care unit with deaths. These data reflect the serious situation of abuse of drugs, revealing that problems, especially those related to alcohol consumption, are alarming ${ }^{(12,18)}$. The service to the person who is a user of drugs, most often, is focused on injury caused by physical trauma or in clinical changes resulting from chronic substance use, not including a "look" for the use of drugs per se, which is not considered a health problem subject to immediate intervention. Thus, drug use is not normally identified as the cause motivating the care in health services, strengthening the gap in the surveillance of the use of drugs of abuse ${ }^{(18)}$.

It is not possible to measure the real magnitude of the problem investigated, since not all hospitals have toxicological activities for reporting cases intoxication by drug abuse, and also Brazil has one of the largest markets for drugs of abuse ${ }^{(4)}$, a situation that fosters the access to such substances.

The hospital environment, especially the units of attention to the emergency room, is an important source for the detection of cases of intoxication by drugs of abuse. This is the priority site for the development of epidemiological surveillance activities, as well as it is an opportunity to sensitize the user with respect to the risk of such behaviors and about the medical and psychosocial consequences of using drugs of abuse.

\section{Conclusion}

The data confirm that consumption of drugs of abuse influences morbidity and mortality, particularly in men aged at 60 years or above and with low level of education. Mortality was significantly correlated with use of alcohol, injuries with cold weapons and firearms, and the incidence of liver cirrhosis. Furthermore, it was observed a higher mortality in long-term hospitalized patients and people hospitalized in the intensive care unit. 


\section{Collaborations}

Reis LM and Gavioli A contributed to the design, collection of field data, analysis, data interpretation and writing of the article. Antunes F, Silvino MCS and Rosa NM contributed to the collection, analysis, interpretation of data and relevant critical review of the article. Oliveira MLF contributed to the project design, article writing and final approval of the version to be published.

\section{References}

1. Okumura Y, Shimizu S, Ishikawa KB, Matsuda $\mathrm{S}$, Fushimi K, Ito H. Comparison of emergency hospital admissions for drug poisoning and major diseases: a retrospective e observational study using a nationwide administrative discharge database. BMJ Open [Internet]. 2012 [cited 2016 Jan. 20];2:e001857. Available from: http:// bmjopen.bmj.com/content/2/6/e001857.full

2. Jang HS, Kim JY, Choi SH, Yoon YH, Moon SW, Hong YS, et al. Comparative analysis of acutetoxic poisoning in 2003 and 2011: Analysis of 3 academic hospitals. J Korean Med Sci. 2013; 28(10):1424-30.

3. Fonseca AM, Galduróz JCF, Noto AR, Carlini ELA. Comparison between two house hold surveys on psychotropic drug use in Brazil: 2001 and 2004. Ciênc Saúde Coletiva. 2010; 15(3):663-70.

4. United Nations. World drug report 2013. New York: United Nations Office on Drugs and Crime. United Nations [Internet]. 2013 [cited 2016 Jan. 20]. Available from: http://www.unodc.org/ unodc/secured/wdr/wdr2013/World_Drug_ Report_2013.pdf

5. Oliveira GC, Dell'Agnolo CM, Ballani TSL, Carvalho MDB, Pelloso SM. Consumo abusivo de álcool em mulheres. Rev Gaúcha Enferm. 2012; 33(2):60-8.
6. Santana CJ, Silvino MCS, Rosa NM, Almeida EG, Reis LM, Oliveira MLF. Potencialidade de um evento sentinela para vigilância epidemiológica do abuso de drogas. Rev Enferm UFPE On line [periódico na Internet]. 2014 [citado 2015 nov 19]; 8(12). Disponível em: http://www.revista. ufpe.br/revistaenfermagem/index.php/revista/ article/download/7013/1104

7. Secretaria de Estado da Saúde de São Paulo. Centro de Vigilância Sanitária, Núcleo de Toxicovigilância. Manual de Toxicovigilância, Cadernos de Toxicovigilância 1 [Internet]. 2014 [citado 2015 nov 19]; Disponível em: http:// www.cvs.saude.sp.gov.br/zip/Caderno\% 20 de $\% 20$ Toxicovigil\%C 3\%A 2ncia \% 20 I $\% 20$ 15.04.2014\%20final.pdf

8. Arreaza ALV, Moraes JC. Vigilância da saúde: fundamentos, interfaces e tendências. Ciênc Saúde Coletiva. 2010; 15(4):2215-28.

9. Mota DM, Melo JRR, Freitas DRC, Machado M. Perfil da mortalidade por intoxicação com medicamentos no Brasil, 1996-2005: retrato de uma década. Ciênc Saúde Coletiva. 2012; 17(1):6170 .

10. Moreira MM, Galera SAF. Assessment of alcohol use in families of the suburbs of Guayaquil city, Ecuador, by nursing students. Rev Latino-Am Enfermagem. 2010; 18(spec):620-5.

11. Miguel-Bouzas JC, Castro-Tubío E, BermejoBarrera AM, Fernández-Gómez P, Estévez-Núñez JC, Tabernero-Duque MJ. Estudio epidemiológico de las in toxicaciones agudas atendidas en un hospital gallego entre 2005 y 2008. Adicciones. 2012; 24(3):239-46.

12. Saunders K, Brain S, Ebmeier KP. Diagnosing and managing psychosis in primary care. Practitioner. 2011; 255(1740):17-20.

13. Feltran GS. O valor dos pobres: a aposta no dinheiro como mediação para o conflito social contemporâneo. Cad CRH. 2014; 27(72):495-512. 
14. Laranjeira R, Pinsky I, Sanches M, Zaleski M, Caetano R. Alcohol use patterns among brazilian adults. Rev Bras Psiquiatr. 2010; 32(3):231-41.

15. Azevedo RCS, Oliveira KD, Lima e Silva LFA, Koller K, Marques ACPR, Ribeiro M, et al. Abuso e dependência de múltiplas drogas. Rio de Janeiro: Associação Brasileira de Psiquiatria; 2012.

16. Reis LM,Uchimura TT, Oliveira MLF. Socioeconomic and demographic profile in a vulnerable community to the use of drugs of abuse. Acta Paul Enferm. 2013; 26(3):276-82.
17. Barbosa TLA, Xavier-Gomes LM, Barbosa VA, Caldeira AP. Mortalidade masculina por causas externas em Minas Gerais, Brasil. Ciênc Saúde Coletiva. 2013; 18(3):711-9.

18. Souza J, Assad FB, Barbosa SP, Badagnan HF, Almeida LY, Garla CC. Mental health care situations in family health units: perception of community health agents. Texto Contexto Enferm. 2015; 24(1):204-11. 